Volume 12, Nomor 2, November 2020, pp 187-202 Copyright (C) 2017

Jurnal Akuntansi, Program Studi Akuntansi, Fakultas Ekonomi, Universitas Kristen Maranatha. ISSN 2085-8698 | e-ISSN 2598-4977. http://journal.maranatha.edu

\title{
Relevansi Nilai Earning per Share, Price Book Value, Cash Flow, Current Ratio dan Harga Saham: Return on Asset Sebagai Pemoderasi
}

\author{
Arry Eksandy ${ }^{1}$ \\ Fakultas Ekonomi dan Bisnis \\ Program Studi Akuntansi-Univ. Muhammadiyah Tangerang \\ (Jl. Perintis Kemerdekaan I No.33 Cikokol Tangerang, Banten) \\ arry.eksandy@yahoo.com \\ Dirvi Surya Abbas ${ }^{2}$ \\ Fakultas Ekonomi dan Bisnis \\ Program Studi Akuntansi-Univ. Muhammadiyah Tangerang \\ (Jl. Perintis Kemerdekaan I No.33 Cikokol Tangerang, Banten) \\ abbas.dirvi@gmail.com
}

\begin{abstract}
The purpose of this study is to determine the results of Earnings Per Share, Book Value Equity, Operating Cash Flow, Investment Cash Flow, Funding Cash Flow, Current Ratio, Asset Returns and Asset Returns moderate Operating Cash Flow to Share Prices in manufacturing companies found in Indonesia stock exchange. This research population publishes manufacturing companies listed on the Indonesia Stock Exchange (IDX) for the 2015-2018 period. The sampling technique uses purposive sampling technique. Based on predetermined criteria the number of samples obtained by 9 companies. The type of data used in this study is secondary data using panel data regression analysis methods. The results showed that Earnings Per Share and Book Value of Equity showed a positive effect on the Share Price, then, Funding Cash Flow, Return on Assets and Return on Assets moderate the Operating Cash Flow negatively evaluating the Stock Price. Whereas Operating Cash Flow, Investment Cash Flow, and Current Ratio do not affect the stock price.
\end{abstract}

Keywords: Stock Prices, Cash Flow, Finance Ratio 


\begin{abstract}
Abstrak
Tujuan dari penelitian ini untuk mengetahui pengaruh Laba Per Lembar Saham, Nilai Buku Ekuitas, Arus Kas Operasi, Arus Kas Investasi, Arus Kas Pendanaan, Current Ratio, Return on Asset dan Return on Asset memoderasi Arus Kas Operasi terhadap Harga Saham pada perusahaan manufaktur yang terdaftar di Bursa Efek Indonesia. Populasi penelitian ini meliputi perusahaan manufaktur yang terdaftar di Bursa Efek Indonesia (BEI) periode 2015-2018. Teknik pengambilan sampel menggunakan teknik purposive sampling. Berdasarkan kriteria yang telah ditetapkan diperoleh jumlah sampel 9 perusahaan. Jenis data yang digunakan dalam penelitian ini adalah data sekunder dengan menggunakan metode analisis regresi data panel. Hasil penelitian menunjukkan bahwa Laba Per Lembar Saham dan Nilai Buku Ekuitas berpengaruh positif terhadap Harga Saham, lalu, Arus Kas Pendanaan, dan Return on Asset berpengaruh negatif. Serta Return on Asset dapat memoderasi Arus Kas Operasi dengan menghasilkan pengaruh negatif terhadap harga Saham. Sedangkan Arus Kas Operasi, Arus Kas Investasi, dan Current Ratio tidak berpengaruh terhadap harga Saham.
\end{abstract}

\title{
Kata Kunci: Harga Saham, Komponen Arus Kas, Rasio Keuangan
}

\section{Pendahuluan}

Dalam berinvestasi di pasar modal terutama di dunia pasar saham. investor yang cerdas akan selalu menggunakan rasionalnya dalam pemahaman serta menggunakan analisis keuangannya dengan baik terkait perihal instrumen investasi serta kemampuan dalam mengumpulkan informasi yang lengkap tentang perusahaan yang akan ditanamkan uangnya. Dalam menilai kinerja perusahaan yang didasari oleh adanya transaksi di pasar efek akan memiliki risiko tersendiri. Sehingga dalam rangka mempermudah investor dalam memahaminya, pasar efek sudah mempersiapkan berbagai macam informasi keaungan perusahaan yang sewaktu-waktu dapat digunakan oleh investor dalam rangka pertimbangannya dalam pengambilan keputusan investasi nantinya, dikhususkan terutama bagi para investor yang benarbenar memiliki kemauan untuk menanamkan modalnya di perusahaan yang sudah terdaftar di bursa efek indonesia.

Adanya penjualan saham secara besarbesaran yang dilakukan oleh para pelaku pasar, khususnya terhadap saham-saham sektor tertentu mempengaruhi indeks sektor tersebut merosot hingga 5,08\%. Hal Ini merupakan suatu penurunan yang jarang terjadi sepanjang tahun 2015-2018. sehingga, Indeks Harga Saham Gabungan (IHSG) pun terseret dan ditutup melemah $1,72 \%$ ke level $5.874,15$ poin. (Katadata.com)

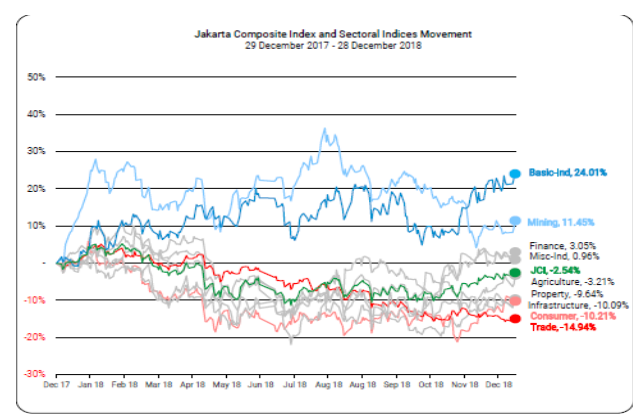

\section{Grafik 1 \\ Indeks Saham Perusahaan yang Terdaftar di BEI 2015-2018}

Grafik diatas menjelaskan Indeks dari saham perusahaan yang mengalami penurunan dari 1,51 poin menjadi 0,42 poin sedangkan begitu pula diikuti oleh indeks sektor perusahaan lainnya yang mengalami kemerosotan dari 1,31 poin menjadi 1.11 poin. 
Berikut adalah perusahaan-perusahaan manufaktur yang memiliki harga saham dari tahun 2015-2018 dan perusahaan tersebut sudah berdiri lebih dari 10 tahun. Pastinya dipengaruhi oleh tingkat Laba yang diperoleh, selain menjadi salah satu tujuan perusahaan sebagai institusi bisnis. Dalam mencapai tujuannya, perusahaan harus inovatif dan mampu melakukan penyesuaian diri terhadap perubahanperubahan di regional dan dalam negeri seperti kebijakan-kebijakan pemerintah dan kondisi politik. Adapun perusahaan manufaktur yang akan menjadi sampel penelitian yang terdaftar di Bursa Efek Indonesia berjumlah 9 perusahaan. Berikut adalah data perusahaan manufaktur yang terdfatar di Bursa Efek Indonesia per 31 Desember 2015-2018:

\section{Tabel 1}

Perusahaan Manufaktur yang Terdaftar di Bursa Efek Indonesia per 31 Desember 2015-2018:

\begin{tabular}{|l|l|l|l|}
\hline No & Saham & \multicolumn{1}{|c|}{ Emiten } & \multicolumn{1}{|c|}{ IPO } \\
\hline 1. & AMFG & Asahimas Flat Glass Tbk. & 08-Nov-1995 \\
\hline 2. & DVLA & Darya-Varia Laboratoria Tbk. & 11-Nov-1994 \\
\hline 3. & INTP & Indocement Tunggal Prakarsa Tbk. & 05-Dec-1989 \\
\hline 4. & JPFA & Japfa Comfeed Indonesia Tbk. & 23-Oct-1989 \\
\hline 5. & KLBF & Kalbe Farma Tbk. & 30-Jul-1991 \\
\hline 6. & ROTI & Nippon Indosari Corpindo Tbk. & 28-Jun-2010 \\
\hline 7. & SCCO & $\begin{array}{l}\text { Supreme Cable Manufacturing \& } \\
\text { 20-Jul-1982 }\end{array}$ \\
\hline 8. & SMGR & Sommerce Tbk. & \\
\hline 9. & TSPC & Tempo Scan Pacific Tbk. & 08-Jul-1991 \\
\hline
\end{tabular}

Sumber : www.idx.co.id

Di tahun 2014 terjadi fenomena kasus pada ekonomi secara global yang berimbas kepada kebijakan restrukturisasi keuangan di Indonesia sehingga memasuki keterlambatan pertumbuhan disebabkan adanya dilema yang dihadapi oleh kemajuan diberbagai aspek bidang industri perusahaan yang bertempat di Indonesia adapun dilema yang dihadapinya terkait dengan tingginya suku bunga sebesar 7,5\% diikuti dengan kenaikan harga dasar listrik industri terhitung mulai diawal bulan Mei 2014. Pengaruh dari hal tersebut berdampak kepada biaya di berbagai aspek industri diperusahaan sebab tingginya akan suku bunga tersebut membuat konsumsi masyarakat menjadi tertekan seperti mulainya minat masyarakat dalam pembelian motor terutama mobil yang menjadi alasan mengapa perusahaan industri logam mengalami penurunan untuk berkembang, sehingga pendapatan perusahaan tersebut tidak dapat menutupi biaya tentang kenaikan konsumsi listrik dalam rangka menambah menjalankan produksinya.

Pada tahun 2015 lalu, tingkat pertumbuhan ekonomi global mendapati ketidakpastian. Hal tersebut diungkapkan oleh IMF (International Monitery Bank) di awal tahun 2016, dalam pertemuan World Economic Outlook, yang menyatakan bahwa jika laju peningkatan ekonomi di Negara tirai bamboo (china) sedang memasuki laju pertumbuhan ekonomi yang lambat, hal tersebut diluar dugaan IMF (International Monetary Bank). Sehingga, banyak kegiatan impor maupun ekspor di Negara tirai bambu (China) tersebut yang didapatkan mengalami kegagalan keuangan terutama dalam aktivitas usaha investasi serta aktivitas manufaktur.

Adapun dampak kasus yang terjadi dari pengaruh ketidakstabilan perekonomian dunia terhadap Indonesia ialah kepada perusahaan manufaktur sektor industri. Pada periode akhir tahun 2016 Bursa Efek Indonesia (BEI) memberitahukan kepada publik perihal informasi tentang penurunan pendapatan disektor aneka industri yang turun hingga $3,05 \%$ ke level 1.271.541 dari posisi awal sempat menguat diposisi 1.311 .625 untuk saham emiten otomotif dan suku cadang. salah satu contohnya yakni kode perusahaan ASII, yang menurun ke level 7,575 dari posisi sebelumnya sebesar 7,850 serta perusahaan otomotif sejenisnya seperti perusahaan otomotif yang berkode GJTL yang mengalami penurunan hingga ke level 1.085 dari posisi awal sebesar 1.130. 


\section{Kerangka Teoritis dan Hipotesis}

Konsep relevansi nilai informasi akuntansi yang menekankan pada bagaimana informasi akuntansi harus memiliki nilai informasi yang relevan untuk para pengguna laporan keuangan yakni investor. Dengan kata lain laporan keuangan yang memiliki nilai Inforrnasi yang handal dan relevan haruslah terkandung suatu informasi yang dapat dapat dijadikan suatu acuan dalam pengambilan suatu keputusan tepat bagi para investor. Konsep ini pada dasarnya menggambarkan tentang bagaimana respon investor ketika menanggapi informasi akuntansi yang disebarluaskan ke publik oleh lembaga keuangan. Jika terdapatnya suatu respon dari kalangan investor terkait penyebarluasan informasi akuntansi ini, maka hal tersebut dapat menunjukkan bahwa nilai informasi akuntansi yang terdapat dalam laporan keuangan tersebut merupakan suatu isu yang layak ditanggapi dan dijadikan acuan dalam proses pengambilan keputusan untuk berinvestasi.

Merujuk kepada hasil Penelitian Putra, Handayani, \& Pambudi, (2013) dikatakan bahwa suatu relevansinya informasi akuntansi dapat dijelaskan dengan sampai sejauh mana informasi yang terkandung didalam laporan keuangan tersebut dapat menjelaskan secara handal nilai suatu perusahaan tersebut. Pada dasarnya relevansi nilai ditujukan untuk menemukan anomali antara hubungan empiris dengan nilai-nilai pasar saham. Pentingnya suatu informasi akuntansi yang bermanfaat bagi pengguna laporan keuangan dalam memproyeksi nilai yang dikehendaki berdasarkan tingkat pengembalian dan tingkat risiko dari sekuritas.

Selain pentingnya suatu relevansi informasi akuntansi yang terkandung didalam laporan keuangan agar dapat dijadikan suatu keputusan. Terdapat faktor lain yang mempengaruhi return saham. Dalam hasil penelitian yang dilakukan oleh
Feltham \& Ohlson (1995), pada dasarnya dalam penggunaan metode clean surplus terdapat suatu kerangka kerja yang konsisten dengan metode pengukuran yang didasari oleh konsep akrual. dengan asumsi bagaimana menunjukkan nilai pasar dari suatu perusahaan dengan berdasarkan dari komponen - komponen yang ada pada laporan posisi keuangan serta laporan laba (rugi). Situasi ini nantinya dapat dinyatakan bahwa data-data akuntansi yang terdapat didalam laporan keuangan tersebut mempunyai relevansi nilai. Pada dasarnya penelitian relevansi nilai dibuat untuk menentukan tentang manfaat nilai-nilai akuntansi terkait tentang penilaian ekuitas di perusahaan. Selain itu relevansi nilai merupakan suatu pelaporan yang digambarkan dengan angka-angka akuntansi yang memiliki suatu proyeksi berhubungan dengan nilai-nilai pasar efek. Pada dasarnya konsep relevansi nilai ini tidak terlepas dari adanya kriteria relevansi berdasarkan standar akuntansi keuangan karena ukuran suatu angka akuntansi akan menjadi lebih relevan jika hasil yang disajikan menggambarkan informasiinformasi yang relevan sesuai dengan fakta di perusahaan.

Setelah membahas tentang adanya keterkaitan relevansi nilai dan metode clean surplus. Keterkaitan berikutnya adalah si pelaku pasar modal itu sendiri. biasanya para pelaku pasar modal selalu mengikuti naik/ turunnya nilai harga saham serta akan selalu mencari informasi tentang perusahaan yang akan di investasikannya, dalam rangka untuk menentukan harga saham. Respon pasar modal terhadap informasi yang beredar dapat dijadikan dalam mengukur atau menguji keberagaman informasi yang berkembang.

Menurut (Lako, 2005) teori pasar efisien memproyeksikan bahwa pasar saham akan bereaksi dengan cepat dan tepat terhadap suatu pemberitahuan informasi baru atau peristiwa spesifik tertentu dan reaksi tersebut digambarkan dengan perubahan atau pergerakan harga - harga 
saham selama masa pemberitahuan informasi atau kejadian suatu peristiwa yang bersifat spesifik. Jika berdampak akan perubahan harga-harga sekuritas, maka pemberitahuan informasi baru tersebut atau adanya suatu kejadian serta peristiwa tertentu tersebut, pastilah sudah dapat dikatakan bahwa informasi tersebut memiliki suatu kandungan informasi yang berguna bagi para pelaku pasar saham. begitupun sebaliknya, jika tidak terjadi perubahan harga-harga saham maka pemberitahuan informasi baru atau kejadian tertentu tersebut tidak mempunyai kandungan informasi dan tidak begitu diminati oleh para pelaku pasar saham.

Berdasarkan penjelasan diatas peneliti ingin mencoba mengungkapkan keterkaitan dan mengkonfirmasi keabsahan informasi diatas.

\section{Metode Penelitian}

Adapun pendekatan yang digunakan dalam penelitian ini adalah dengan menggunakan pendekatan kuantitatif. Karena pendekatan kuantitatif memiliki interpretasi dari setiap masing-masing variabel maupun keterkaitan antar variabel dilandaskan oleh skala pengukuran kuantitatif dalam mendapatkan bukti empiris dari situasi return saham menggunakan analisis rasio keuangan perusahaan. Lalu, cara pengukurannya disebut sebagai metode. Adapun metode yang digunakan dalam penelitian ini adalah dengan menggunakan metode kuantitatif. Metode kuantitatif yaitu, suatu metode penelitian yang didasarkan oleh filsafat yang digunakan untuk eksperimen populasi dan sampel tertentu. dalam pengumpulan datanya, menggunakan suatu instrumen penelitian, dengan tujuan untuk menguji hipotesis yang telah ditetapkan berdasarkan analisis data kuantitatif atau statistik, (Sugiyono, 2017).

Data sekunder adalah sumber data yang digunakan dalam penelitian ini. dalam penelitian ini nantinya akan menguji keterkaitan kausal atau pengaruh dari masing-masing variabel yang terdiri dari variabel independen yaitu Laba per Lembar Saham, Nilai Buku Ekuitas, Arus Kas Operasi, Arus Kas Investasi, Arus Kas Pendanaan, Current Ratio, Return on Asset terhadap variabel dependen yaitu Return Saham dengan diperkuat/ diperlemah oleh variabel moderasi yaitu Arus Kas Operasi pada perusahaan Manufaktur yang terdaftar di Bursa Efek Indonesia periode 2015-2018.

Karena sering terjadinya kesalahpahaman dalam artikel ilmiah tentang Populasi dan Sampel. Maka akan dibahas sedikit disini pengertian Populasi dengan Sampel menurut para ahlinya. Populasi merupakan suatu zona penyeragaman terkait objek/ subjek dengan kualitas serta karakteristik yang sesuai dengan yang telah ditetapkan dalam rangka untuk mempelajari serta diambil suatu kesimpulannya (Sugiyono, 2017). Lalu, sampel adalah komponen dari suatu penjumlahan serta memiliki sifat dan ciri yang sama seperti populasi tersebut (Sugiyono, 2017).

Berdasarkan penjelasan tersebut maka kita dapat mengetahui, bahwa perusahaan jenis manufaktur yang terdaftar di Bursa Efek Indonesia (BEI) 2015-2018 adalah sebanyak 180 perusahaan. Metode yang digunakan dalam menentukan sampel yang digunakan didalam penelitian ini menggunakan metode purposive sampling. Berikut adalah kriteria dalam pemilihan sampel berdasarkan perusahaan manufaktur selama periode yang ditentukan. Adapun sampel yang diinginkan dengan kriteria tertentu adalah sebagai berikut:

- Perusahaan sudah berdiri lebih dari 10 Tahun.

- Menerbitkan laporan keuangan selama periode 2015-2018.

- Menggunakan mata uang rupiah.

- Tidak mengalami kerugian secara berturut-turut.

- Menyediakan informasi lengkap mengenai variabel yang akan diukur dan data yang dibutuhkan tersedia lengkap didalam laporan keuangan. 
Berdasarkan dari kriteria yang telah ditetapkan diawal terkait pengambilan data, maka terdapat 9 Perusahaan yang layak digunakan dikali dengan dengan 4 tahun pengamatan. Dengan begitu didapatkan jumlah total sampel penelitian sebanyak 36 . Hal itu dikarenakan terdapat 78 Perusahaan belum memiliki umur genap 10 tahun, lalu 78 Perusahaan tidak konsisten dalam melaporkan keuangannya dan 23 Perusahaan mengalami kerugian berturut turut. Setelah terkumpul data yang telah ditentukan maka analisis yang dilakukan diawal dalam penelitian ini yakni analisis deskriptif. Tujuan dari penggunaan analisis ini adalah sebagai gambaran keterkaitan korelasi antar variabel. Dalam menganalisisnya dengan memperhatikan hasil nilai output yakni mean, standar deviasi, maksimum, dan minimum. Maka dari itu, dapat dikatakan pengujian analisis deskriptif akan diuji terlebih dahulu didalam penelitian ini. Untuk memastikan apakah keterkaitan-keterkaitan antar variabel yang diteliti sudah terdistribusi dengan normal atau belum. lalu, apakah data yang akan digunakan sudah terbebas dari sifat multikolinearitas atau tidak. Jika model penelitian yang digunakan adalah CEM (Common Effect Model) Dan apakah data terbebas dari sifat heteroskedastisitas atau tidak Jika model penelitian yang digunakan adalah FEM (Fixed Effect Model). Namun pengujian multikolinearitas dan heteroskedastisitas tidak berlaku jika model penelitian yang digunakan adalah REM (Random Effect Model).

Adapun beberapa tahap memastikan layak atau tidaknya model regresi data panel yang akan digunakan dalam penelitian ini dalam menganalisis regresi data panel, menurut prosedur harus melalui beberapa rangkaian tahap pengujian:

- Tahap pengujian yang pertama adalah Uji Chow, uji chow adalah suatu pengujian yang digunakan untuk menentukan analisis model regresi data panel dalam penelitian ini manakah yang lebih layak, apakah menggunakan menggunakan analisis model regresi data panel (CEM) common effect model atau model penelitian fixed effect model (FEM). Pengujian ini dapat dilihat jika probabilitas > 0,05 maka menerima $\mathrm{H}_{0}$, berarti menggunakan pendekatan common effect (pooled least square).Tetapi jika probabilitas $<0,05$ maka $\mathrm{H}_{0}$ ditolak, dan menerima $\mathrm{H}_{1}$, berarti menggunakan pendekatan fixed effect (Eksandy \& Heriyanto, 2017).

- Uji Hausman, digunakan dalam mencari analisis model regresi data panel yang paling tepat digunakan dalam penelitian ini apakah analisis model regresi data panel fixed effect atau analisis model regresi data panel random effect. Dengan ketentuan jika probabilitas > 0,05 maka menerima H0, berarti menggunakan pendekatan random effect. Tetapi jika probabilitas $<0,05$ maka H0 ditolak, dan menerima H1. Berarti menggunakan pendekatan fixed effect. (Eksandy \& Heriyanto, 2017)

- Uji lagrange multipler (LM) dilakukan untuk mengetahui apakah model yang digunakan adalah common effect model atau dengan random effect model. Pengujian ini dapat dilihat pada nilai probabilitas breusch-pagan. Jika nilai Probabilitas Cross-section breusch pagan > $\alpha(0.05)$, maka H0 diterima sehingga model yang digunakan adalah common effect model. Akan tetapi, jika nilai Probabilitas Cross-section breuschpagan < $\alpha(0.05)$, maka H0 ditolak dan model yang digunakan adalah random effect model. (Eksandy \& Heriyanto, 2017)

Penelitian ini dilengkapi dengan Uji asumsi klasik. Adapun jenis uji asumsi klasik ialah suatu persyaratan rangkaian prosedur statistik dalam menganalisis suatu regresi dengan menggunakan pendekatan model regresi data panel penelitian FEM dan CEM (Eksandy \& Heriyanto, 2017) sehingga mendapatkan:

- Uji Multikolinearitas, ialah suatu adanya korelasi antar variabel eksogen 
(Eksandy \& Heriyanto, 2017) dalam mencari multikolinearitas di dalam model regresi data panel penelitian dengan memperhatikan nilai atas koefisien variabel eksogen.

- Uji Heteroskedastisitas, untuk memastikan bahwa model regresi data panel penelitian bebas dari ketidaksamaan varian yang diakibatkan dari residual model penelitian.

Pengungkapan hipotesis dalam penelitian ini dengan alat uji analisis regresi data panel.

- Pengujian Uji F mengungkapkan bahwa apakah semua variabel eksogen yang digunakan kedalam model pengujian, sudah dapat dikatakan sebagai model pengujian yang layak atau tidak.

- Pengujian nilai koefisien determinasi mengungkapkan tentang bagaimana model regresi dalam kemampuan menjelaskan keanekaragaman variabel eksogen dalam berinteraksi terhadap variabel endogen.

- Pengujian nilai R-squared mengungkapkan seberapa tinggi nilai variabel eksogen dalam memberikan interaksi naik/turun suatu variabel endogen. Jika, semakin besar hasil dari nilai $R$-squared ini, maka menunjukkan variabel eksogen dapat dengan akurat mengidentifikasi dalam mengungkapkan variabel endogen.

- Pengujian uji t (parsial) mengungkapkan tentang adanya tingkat signifikan dari interaksi variabel eksogen secara parsial kepada variabel endogen.

Adapun perhitungan tentang persamaan regresi data panel dalam penelitian ini sebagai berikut:

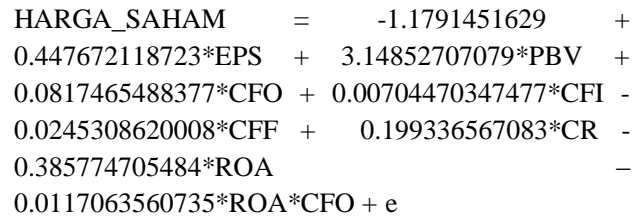

- Konstanta (C) sebesar $\quad-1.179$ menunjukkan bahwa apabila Earning Per Share, Price Book Value, Cash Flow Operation, Cash Flow Investment, Cash Flow Finance, Current Ratio, dan Return on Asset konstan maka akan menurunkan nilai dari Harga Saham sebesar -1.179.

- Coefficient Earning Per Share (EPS) sebesar 0.448 menunjukkan bahwa setiap kenaikan 1 (satu) untuk Earning Per Share (EPS) akan meningkatkan Harga Saham 0.448 dengan estimasi Coefficient variabel lainnya dianggap konstan.

- Coefficient Price Book Value (PBV) sebesar 3.148 menunjukkan bahwa setiap kenaikan 1 (satu) pada Price Book Value (PBV) akan meningkatkan Harga Saham 3.148 dengan estimasi Coefficient variabel lainnya dianggap konstan.

- Coefficient Cash Flow Operation (CFO) sebesar 0.082 menunjukkan bahwa setiap kenaikan 1 (satu) pada Cash Flow Operation (CFO) akan meningkatkan Harga Saham 0.082 dengan estimasi Coefficient variabel lainnya dianggap konstan.

- Coefficient Cash Flow Invesment (CFI) sebesar 0.007 menunjukkan bahwa setiap kenaikan 1 (satu) pada Cash Flow Invesment (CFI) akan meningkatkan Harga Saham 0.007 dengan estimasi Coefficient variabel lainnya dianggap konstan.

- Coefficient Cash Flow Finance (CFF) sebesar -0.024 mengungkapkan bahwa dalam setiap sebesar 1 peningkatan pada variabel Cash Flow Finance (CFF) akan berdampak pada menurunnya nilai harga saham -0.024 dengan estimasi Coefficient variabel lainnya dianggap konstan.

- Coefficient Current Ratio (CR) sebesar 0.199 mengungkapkan bahwa dalam setiap sebesar 1 peningkatan pada Current Ratio (CR) akan berdampak pada meningkatnya harga saham 0.199 
dengan estimasi Coefficient variabel lainnya dianggap konstan.

- Coefficient Return on Asset (ROA) sebesar -0.385 mengungkapkan bahwa setiap sebesar 1 peningkatan pada Return on Asset (ROA) akan berdampak pada menurunnya harga saham -0.385 dengan estimasi Coefficient variabel lainnya dianggap konstan.

- Coefficient Return on Asset (ROA) memoderasi Arus Kas Operasi (CFO) sebesar -0.011 menunjukkan bahwa setiap sebesar 1 peningkatan pada harga saham akan berdampak pada menurunnya harga Saham -0.011 dengan estimasi Coefficient variabel lainnya dianggap konstan.

\section{Hasil Penelitian dan Pembahasan}

Berikut adalah hasil pengujian analisis statistik deskriptif dari variabel endogen yaitu Harga Saham maupun variabel independen yang terdiri dari Earning Per Share, Price Book Value, Cash Flow Operation, Cash Flow Investment, Cash Flow Finance, Current Ratio, dan Return on Asset.

Tabel 1

\section{Hasil Uji Deskriptif}

\begin{tabular}{|l|c|c|c|c|c|c|c|c|}
\hline & $\begin{array}{c}\text { HARGA_S } \\
\text { AHAM }\end{array}$ & EPS & PBV & CFO & CFI & CFF & CR & ROA \\
\hline \hline Mean & 5.4619 & 3.5476 & 2.4941 & 12.505 & -11.607 & 2.7208 & 2.6947 & 8.0172 \\
Median & 1.9650 & 1.2850 & 1.9350 & 3.1700 & -1.9650 & 0.0000 & 2.5300 & 8.1350 \\
Maximum & 22.330 & 16.560 & 6.0100 & 96.110 & 0.0000 & 253.27 & 4.8900 & 15.760 \\
Minimum & 0.0100 & -2.1000 & 0.4600 & -34.100 & -96.730 & -87.880 & 1.2700 & -1.1100 \\
Std. Dev. & 6.1655 & 4.4218 & 1.7206 & 29.022 & 22.560 & 46.132 & 1.0386 & 4.3173 \\
Skewness & 1.4177 & 1.2993 & 0.9807 & 1.6113 & -2.4588 & 4.4097 & 0.6413 & -0.0382 \\
Kurtosis & 4.1488 & 3.7622 & 2.6952 & 5.2596 & 8.3390 & 26.019 & 2.2779 & 2.3677 \\
Jarque-Bera & 14.040 & 11.002 & 5.9099 & 23.237 & 79.034 & 911.48 & 3.2498 & 0.6083 \\
Probability & 0.0008 & 0.0040 & 0.0520 & 0.0000 & 0.0000 & 0.0000 & 0.1969 & 0.7377 \\
Sum & 196.63 & 127.71 & 89.790 & 450.18 & -417.86 & 97.950 & 97.010 & 288.62 \\
Sum Sq. Dev. & 1330.4 & 684.33 & 103.62 & 29480. & 17814. & 74488. & 37.758 & 652.38 \\
Observations & 36 & 36 & 36 & 36 & 36 & 36 & 36 & 36 \\
\hline
\end{tabular}

Nilai mean tertinggi diperoleh variabel Cash Flow Operation (CFO) yakni sebesar 12.50, sementara variabel Cash Flow Investment (CFI) memperoleh nilai mean terendah yakni sebesar -11.60 .
Median tertinggi diperoleh oleh variabel Return on Asset (ROA) yaitu sebesar 8,14, sementara variabel Cash Flow Investment (CFI) memiliki median terendah yaitu sebesar -1,96.

Maximum adalah data yang memiliki nilai paling tinggi (Winarno, 2015). Maximum tertinggi diperoleh variabel Cash Flow Finance (CFF) yaitu sebesar 253.3, sementara variabel Cash Flow Investment (CFI) memiliki maximum terendah yaitu sebesar 0,00 .

Minimum adalah data yang memiliki nilai paling rendah (Winarno, 2015) Minimum tertinggi diperoleh variabel Current Ratio (CR) yaitu sebesar 1.27, sementara variabel Cash Flow Investment (CFI) memiliki minimum terendah yaitu sebesar $-96,7$.

Nilai Std. dev tertinggi didapatkan oleh variabel Cash Flow Finance (CFF) yaitu sebesar 46.2, yang menunjukkan bahwa variabel tersebut memiliki estimasi tingkat rawan risiko jika disandingkan dengan variabel pengamatan lainnya. Lalu, variabel yang memiliki tingkat kerawanan resiko terendah ialah Current Ratio (CR), yakni sebesar 1,04, Hal tersebut dikarenakan selama periode tahun pengamatan melalui suatu situasi perubahan yang tidak begitu fluktuatif.

Skewness dapat dikatakan normal jika suatu distribusi simetris memiliki nilai nol. Positive skewness mengartikan bahwa jika penyebaran data condong ekornya panjang di sebelah kanan, lain hal jika mendapatkan nilai skewness condong ekor panjang di kiri itu menandakan bahwa jika data tidak menyebar dengan normal atau data negatif (Winarno, 2015). variabel Cash Flow Investment (CFI) dan Return on Asset (ROA) memiliki nilai negatif. Untuk variabel Harga Saham, Earning Per Share (EPS), Price Book Value (PBV), Cash Flow Operation (CFO), Cash Flow Finance (CFF) dan Current Ratio (CR) memiliki nilai positif.

Untuk variabel financial Harga Saham, Earning Per Share (EPS), Cash 
Flow Operation (CFO), Cash Flow Invesment (CFI), dan Cash Flow Finance (CFF) memiliki nilai kurtosis lebih dari 3. Untuk variabel Price Book Value (PBV), Current Ratio (CR), dan Return on Asset (ROA) memiliki nilai kurang dari 3.

Dalam penelitian ini, dapat ditentukan bahwa model Fixed Effect Model lebih tepat digunakan untuk lanjut dalam mengestimasi pengaruh Per Share, Price Book Value, Cash Flow Operation, Cash Flow Investment, Cash Flow Finance, Current Ratio terhadap Harga Saham dengan dimoderasi Return on Asset (ROA). Terdapat 9 perusahaan manufaktur yang dijadikan sampel dalam penelitian ini selama periode 2015-2018.

Tabel 2

\section{Hasil Uji multikolinearitas}

\begin{tabular}{|c|c|c|c|c|c|c|c|c|}
\hline & $\begin{array}{l}\text { HARGA } \\
\text { SAHAM }\end{array}$ & EPS & PBV & CFO & CFI & CFF & $\mathrm{CR}$ & ROA \\
\hline \multicolumn{9}{|c|}{ HARGA_SAHA } \\
\hline$M$ & 1.0000 & 0.5934 & -0.1557 & -0.2713 & 0.1900 & -0.0687 & 0.1509 & -0.0116 \\
\hline EPS & 0.5934 & 1.0000 & -0.3278 & -0.1758 & 0.0785 & -0.0831 & -0.0350 & 0.3122 \\
\hline PBV & -0.1557 & -0.3278 & 1.0000 & 0.2138 & -0.0835 & 0.2486 & 0.4755 & 0.4738 \\
\hline CFO & -0.2713 & -0.1758 & 0.2138 & 1.0000 & -0.6367 & 0.3167 & -0.0838 & -0.0389 \\
\hline CFI & 0.1900 & 0.0785 & -0.0835 & -0.6367 & 1.0000 & -0.2382 & 0.1527 & 0.2801 \\
\hline CFF & -0.0687 & -0.0831 & 0.2486 & 0.3167 & -0.2382 & 1.0000 & -0.0693 & -0.0894 \\
\hline $\mathrm{CR}$ & 0.1509 & -0.0350 & 0.4755 & -0.0838 & 0.1527 & -0.0693 & 1.0000 & 0.4970 \\
\hline ROA & -0.0116 & 0.3122 & 0.4738 & -0.0389 & 0.2801 & -0.0894 & 0.4970 & 1.0000 \\
\hline $\mathrm{ROA}^{*} \mathrm{CFO}$ & -0.2234 & -0.0204 & 0.1860 & 0.9064 & -0.3944 & 0.1490 & -0.1015 & 0.1473 \\
\hline
\end{tabular}

Berdasarkan hasil uji multikolinearitas dapat diketahui bahwa hasil dari nilai korelasi yang didapatkan tidak terdapat nilai koefisien yang cukup besar, bahkan semua nilai koefisien korelasi dari setiap variasi variabel berada dibawah nilai 0,8 . Berdasarkan hasil tersebut dapat disimpulkan bahwa tidak ada gejala multikolinearitas dalam data yang digunakan dalam penelitian ini. karena nilai koefisien dari antar variabel independen berada dibawah kriteria standar adanya gejala multikolinearitas dalam suatu data yaitu 0,8 (Eksandy \& Heriyanto, 2017).

\section{Tabel 3 Hasil Uji Multikolinearitas}

Residual Cross-Section Dependence Test

Null hypothesis: No cross-section dependence (correlation) in residuals

Equation: EQ01

Periods included: 4

Cross-sections included: 9

Total panel observations: 36

Cross-section effects were removed during estimation

\begin{tabular}{lccc}
\hline \hline \multicolumn{1}{c}{ Test } & Statistic & d.f. & Prob. \\
\hline \hline & & & \\
Breusch-Pagan LM & 47.02631 & 36 & 0.1033 \\
Pesaran scaled LM & 0.238803 & & 0.8113 \\
Bias-corrected scaled LM & -1.261197 & & 0.2072 \\
Pesaran CD & -0.887754 & & 0.3747 \\
& & & \\
\hline \hline
\end{tabular}

Lalu, berdasarkan hasil uji heteroskedastisitas dapat diketahui bahwa hasil dari estimasi Bruesch-Pagan LM yang didapatkan 0.1033, hal tersebut menunjukkan jika >0,05, maka dapat disimpulkan bahwa model estimasi yang akan digunakan dalam penelitian ini terbebas gejala heteros.

\section{Tabel 4}

\section{Hasil Uji F}

\begin{tabular}{lrll}
\hline \hline \multicolumn{4}{l}{ Cross-section fixed (dummy variables) } \\
\hline \hline & & & \\
\hline R-squared & 0.986769 & Mean dependent var & 5.461944 \\
Adjusted R-squared & 0.975627 & S.D. dependent var & 6.165548 \\
S.E. of regression & 0.962560 & Akaike info criterion & 3.066924 \\
Sum squared resid & 17.60392 & Schwarz criterion & 3.814697 \\
Log likelihood & -38.20464 & Hannan-Quinn criter. & 3.327917 \\
F-statistic & 88.56275 & Durbin-Watson stat & 3.258508 \\
Prob(F-statistic) & 0.000000 & & \\
\hline
\end{tabular}

Sesuai dengan hasil uji $\mathrm{F}$ mengungkapkan bahwa nilai $F_{\text {-statistic }} 88.56275$, dengan nilai $F_{\text {-Tabel }}$ dengan tingkat $\alpha=5 \%, \mathrm{df}_{1}(7-1)=6$ dan $\mathrm{df}_{2}(36-7)=29$ yakni sebesar 2.43 . menunjukkan bahwa jika F-statistic $88.56275>F_{\text {-Tabel }} 2,49$ dengan estimasi Prob $\mathrm{F}_{\text {-statistic }} 0.00<0,05$. maka demikian hal tersebut mengartikan jika Ha diterima, sehingga dapat disimpulkan bahwa model analisis yang digunakan layak untuk digunakan dalam melihat hubungan antara variabel laba per lembar saham, Nilai Buku Perusahaan, Arus Kas Operasi, Arus Kas Investasi, Arus Kas Keuangan, Rasio 
Lancar, dan Laba atas Aset terhadap Harga Saham.

Berdasarkan hasil uji $R$ Adjusted Squared dijelaskan bahwa Adjusted $R$ squared dengan nilai sebesar 0.975627, mengartikan bahwa jika variasi Harga Saham dapat dijelaskan suatu perubahan naik turunnya oleh Earning Per Share, Price Book Value, Cash Flow Operation, Cash Flow Investment, Cash Flow Finance, Current Ratio, dan Return on Asset yakni sebesar $97 \%$, sementara sisanya yaitu sebesar 3\% dijelaskan oleh variabel lainnya yang tidak dimasukkan kedalam penelitian ini.

\section{Tabel 5}

\section{Hasil Uji t}

Dependent Variable: HARGA_SAHAM

Method: Panel Least Squares

Date: 12/22/19 Time: 12:27

Sample: 20152018

Periods included: 4

Cross-sections included: 9

Total panel (balanced) observations: 36

\begin{tabular}{crrrr}
\hline \hline Variable & Coefficient & Std. Error & t-Statistic & Prob. \\
\hline \hline C & -1.179145 & 1.530890 & -0.770235 & 0.4506 \\
EPS & 0.447672 & 0.171367 & 2.612366 & 0.0171 \\
PBV & 3.148527 & 0.614580 & 5.123056 & 0.0001 \\
CFO & 0.081747 & 0.040742 & 2.006447 & 0.0593 \\
CFI & 0.007045 & 0.017176 & 0.410155 & 0.6863 \\
CFF & -0.024531 & 0.006792 & -3.611892 & 0.0019 \\
CR & 0.199337 & 0.394069 & 0.505842 & 0.6188 \\
ROA & -0.385775 & 0.139939 & -2.756742 & 0.0126 \\
ROA*CFO & -0.011706 & 0.004694 & -2.493768 & 0.0220 \\
\hline \hline
\end{tabular}

Pembahasan pengujian uji t (Parsial):

- $t_{\text {-statistic Earning Per Share (EPS) }}$ memiliki nilai 2,616 lain hal $t_{\text {-tabel }}$ dengan sig $\alpha=5 \%$, df $(36-7)=29$ diperoleh nilai $t_{\text {-tabel }}$ sebesar 2.045 . sehingga $\mathrm{t}_{\text {-statistic }}$ Earning Per Share (EPS) 2,616 $>\mathrm{t}_{\text {-tabel }} 2.045$ serta nilai Prob. $t_{\text {statistic }} 0,0171<0,05$. Sehingga dapat dikatakan bahwa $\mathrm{H}_{0}$ ditolak dan $\mathrm{H}_{1}$ diterima, artinya variabel Earning Per Share (EPS) secara parsial memiliki pengaruh positif terhadap Harga Saham, sehingga $\mathrm{H}_{1}$ diterima. Dalam hasil dikatakan bahwa Earning Per Share (EPS) memilki pengaruh positif signifikan dan positif terhadap Harga Saham.

Hal tersebut mengartikan bahwa jika profitabilitas perusahaan terinterpretasi di Earning Per Share (EPS) dengan pasti dalam setiap lembar saham perusahaan tersebut. Earning Per Share (EPS) memiliki pengaruh yang positif terhadap harga saham. Hal tersebut mengartikan bahwa, jika Semakin tinggi Earning Per Share (EPS) maka akan semakin tinggi pula minat para investor dalam berinvestasi diperusahaan tersebut dikarenakan semakin besar laba perusahaan yang dihasilkan oleh perusahaan, maka akan berpengaruh kepada pembagian laba kepada para pemegang saham serta dimungkinkan akan adanya peningkatan jumlah dividen setiap tahunnya. Hasil penelitian ini sejalan dengan hasil penelitian yang dilakukan oleh (G.E.Y.Egam., V.Ilat., 2017) dan (Cahyaningrum \& Antikasari, 2017) yang menyatakan bahwa Earning Per Share (EPS) secara parsial memiliki pengaruh positif terhadap Harga Saham.

- Nilai $t_{\text {-statistic }}$ Price Book Value (PBV) memiliki nilai 5.123056, lain hal $\mathrm{t}_{\text {tabel }}$ dengan sig $\alpha=5 \%$, df (36-7) $=29$ diperoleh nilai $\mathrm{t}_{\text {-tabel }}$ sebesar 2.045 . sehingga $\mathrm{t}_{\text {-statistic }}$ Price Book Value (PBV) 5.123056 > $\mathrm{t}_{\text {-tabel }} 2.045$ dan nilai Prob. $0.0001<0,05$ sehingga dapat diakatakan bahwa $\mathrm{H}_{0}$ ditolak dan $\mathrm{H}_{2}$ diterima, maksudnya bahwa variabel Price Book Value (PBV) secara parsial berpengaruh terhadap Harga Saham. sehingga $\mathrm{H}_{2}$ diterima bahwa terdapat Pengaruh yang signifikan antara Price Book Value (PBV) terhadap Harga Saham.

Dalam hasil penelitian dikatakan bahwa Price Book Value (PBV) memilki pengaruh positif terhadap Harga Saham. Hal tersebut mengartikan bahwa jika PBV memiliki korelasi kuat dengan harga saham. pada dasarnya Price to Book Value (PBV) adalah rasio 
yang digunakan dalam mengukur kevalidan kinerja perusahaan yang menjelaskan harga pasar saham terhadap nilai bukunya. Selain itu Price to Book Value (PBV) juga menunjukkan seberapa baik kemampuan perusahaan dalam menghasilkan nilai perusahaan yang baik terhadap sumber modal yang telah ditanamkan oleh investor. Dapat disimpulkan bahwa kenaikan nilai buku suatu perusahaan maka akan meningkatkan nilai perusahaan yang digambarkan oleh harga saham. Hasil penelitian ini sejalan dengan hasil penelitian yang dilakukan oleh (Cahyaningrum \& Antikasari, 2017) yang menyatakan bahwa Price to Book Value (PBV) berpengaruh terhadap harga saham. Namun, hasil penelitian ini tidak sejalan dengan hasil penelitian yang dilakukan oleh (Abimantrana, 2014) yang menunjukkan bahwa variabel Price to Book Value (PBV) tidak memiliki pengaruh signifikan terhadap harga saham.

- $t_{\text {-statistic }}$ Cash Flow Operation (CFO) memiliki nilai 2.006, lain hal $\mathrm{t}_{\text {-tabel }}$ dengan sig $\alpha=5 \%$, df $(36-7)=29$ diperoleh nilai $t_{\text {-tabel }}$ sebesar 2.045 . sehingga $\mathrm{t}_{\text {-statistic }}$ Cash Flow Operation (CFO) $2.006<\mathrm{t}_{\text {tabel }} 2.045$ dan nilai Prob $0.0593>0,05$ sehingga dapat dikatakan bahwa $\mathrm{H}_{0}$ diterima dan $\mathrm{H}_{3}$ ditolak, artinya variabel Cash Flow Operation (CFO) secara parsial tidak berpengaruh terhadap Harga Saham, dan $\mathrm{H}_{3}$ ditolak bahwa tidak terdapat pengaruh yang signifikan antara Cash Flow Operation (CFO) terhadap Harga Saham.

Dalam hasil penelitian dikatakan bahwa Cash Flow Operation (CFO) tidak memilki pengaruh signifikan dan positif terhadap Harga Saham. Hal tersebut mengartikan bahwa jika kandungan informasi yang terdapat didalam laporan keuangan telah publikasi tersebut memberikan reaksi sinyal yang dapat menarik perhatian para investor dalam mempertimbangkan
Cash Flow Operation (CFO) sebagai acuan dalam pengambilan keputusan penanaman uangnya. Fenomena tidak signifikannya laporan arus kas dari hasil penelitian ini, bisa saja terjadi dikarenakan terdapat beberapa perusahaan yang digunakan dalam penelitian memiliki nilai Cash Flow Operation (CFO) yang tinggi namun disaat yang bersamaan memiliki nilai harga saham yang rendah, begitu pula situasi sebaliknya. sehingga dampak dari informasi yang diterima para investor direspon, untuk tidak berinvestasi di perusahaan tersebut.

Hasil penelitian ini sejalan dengan hasil penelitian yang dilakukan oleh (Badri \& Mayasari, 2016), (Rizal, 2014), (Septya Nisa Sholekhah, Cholid Mawardi, Studi Akuntansi, \& Ekonomi dan Bisnis, 2018) dan (Asrianti \& Rahim, 2015) yang menyatakan bahwa Cash Flow Operation (CFO) tidak memilki pengaruh terhadap Harga Saham. namun hasil penelitian tidak sejalan dengan hasil penelitian yang dilakukan oleh (Sarifudin \& Manaf, 2016) dan (Rawung, Alexander, \& Kalalo, 2017) yang menyatakan bahwa Cash Flow Operation (CFO) memilki pengaruh terhadap Harga Saham.

- Nilai $\mathrm{t}_{\text {-statistic }}$ Cash Flow Invesment (CFI) memiliki nilai 0.410 , lain hal $\mathrm{t}_{\text {-tabel }}$ dengan sig $\alpha=5 \%$, df $(36-7)=29$ diperoleh nilai $t_{\text {-tabel }}$ sebesar 2.045 . sehingga $\mathrm{t}_{\text {-statistic }}$ Cash Flow Invesment (CFI) $0.4101<\mathrm{t}_{\text {-tabel }} 2.045$ dan nilai Prob. $0.686>0,05$ sehingga dapat dikatakan bahwa $\mathrm{H}_{\mathrm{o}}$ diterima dan $\mathrm{H}_{4}$ ditolak, artinya variabel Cash Flow Invesment (CFI) secara parsial tidak berpengaruh terhadap Harga Saham.

Dalam hasil penelitian dikatakan bahwa Cash Flow Invesment (CFI) tidak memilki pengaruh signifikan dan positif terhadap Harga Saham. Hal tersebut mengartikan bahwa jika kandungan informasi yang terdapat didalam laporan keuangan telah 
publikasi tersebut memberikan reaksi sinyal yang dapat menarik perhatian para investor dalam mempertimbangkan Cash Flow Invesment (CFI) sebagai acuan dalam pengambilan keputusan penanaman uangnya. Bahwasannya pelaporan Cash Flow Invesment (CFI) berisi kandungan informasi yang berhubungan dengan pembelian atau penjualan aset, baik aset yang bersifat jangka panjang. Biasanya aset jangka panjang ini dibukukan oleh perusahaan kedalam aset tidak lancar karena sifatnya yang dibeli bukan untuk dijual kembali melainkan untuk kegiatan penunjang perusahaan dalam rangka menghasilkan pendapatan usaha. Adapun jenis aset tersebut seperti tanah, bangunan, kendaraan dan peralatan atau inventaris kantor, serta peyertaan saham hingga investasi penyewaan tempat. Dari penjelasan tersebut dapat disimpulkan bahwa para investor tidak terlalu tertarik dengan kegiatan perusahaan dalam usahanya demi meningkatkan pendapatannya atau mengamankan aset - aset di perusahaannya tersebut. Sehingga informasi tersebut tidak dijadikan sebagai masukan atas informasi yang nantinya akan digunakan dalam mempertimbangkan pengambilan keputusan investasinya.

Hasil penelitian ini sejalan dengan hasil penelitian yang dilakukan oleh (Septya Nisa Sholekhah et al., 2018) yang menyatakan bahwa Cash Flow Invesment $(\mathrm{CFI})$ tidak memilki pengaruh terhadap Harga Saham. namun hasil penelitian ini tidak sejalan dengan hasil penelitian yang dilakukan oleh (Sarifudin \& Manaf, 2016) dan (Rizal, 2014), dan (Asrianti \& Rahim, 2015) yang menyatakan bahwa Cash Flow Invesment (CFI) memilki pengaruh terhadap Harga Saham.

- Nilai t-statistic Cash Flow Finance (CFF) memiliki nilai -3.612 , lain hal $\mathrm{t}_{\text {-tabel }}$ dengan sig $\alpha=5 \%$, df $(36-7)=29$ diperoleh nilai $\mathrm{t}_{\text {-tabel }}$ sebesar 2.045 . sehingga $\mathrm{t}_{\text {-statistic }}$ Cash Flow Finance (CFF) $3.612>t_{\text {. tabel }} 2.045$ dan nilai Prob. $0.0019<0,05$ sehingga dapat dikatakan bahwa $\mathrm{H}_{\mathrm{o}}$ ditolak dan $\mathrm{H}_{5}$ diterima, artinya variabel Cash Flow Finance (CFF) secara parsial berpengaruh terhadap Harga Saham.

Dalam hasil penelitian dikatakan bahwa Cash Flow Finance (CFF) memilki pengaruh signifikan dan negatif terhadap Harga Saham. Hal tersebut mengartikan bahwa jika kandungan informasi yang terdapat didalam laporan keuangan telah publikasi tersebut memberikan reaksi sinyal negatif bagi investor dalam rangka pertimbangannya untuk dijadikan sebagai pengambilan keputusan investasinya tersebut. Investor mengetahui perihal reputasi ini sedang bermasalah keuangan atau tidak berdasarkan dari banyaknya penarikan saham yang dilakukan oleh investor dari perusahaan tersebut atau dari besarnya pinjaman yang tertera didalam laporan Cash Flow Finance (CFF). Karena jika semakin besar pinjaman dari lembaga keuangan yang tertera didalam laporan tersebut, maka investor akan bereaksi bahwa hal tersebut akan mengganggu tentang kelancaran pembayaran deviden disetiap tahunnya. Sehingga hal tersebut membuat para investor untuk berpikir ulang dalam menginvestasikan uangnya diperusahaan tersebut.

Hasil penelitian ini sejalan dengan hasil penelitian yang dilakukan oleh (Sarifudin \& Manaf, 2016), (Rizal, 2014). (Septya Nisa Sholekhah et al., 2018) dan (Asrianti \& Rahim, 2015) yang menyatakan bahwa arus kas pendanaan memiliki pengaruh terhadap harga saham.

- $\mathrm{t}_{\text {-statistic }}$ Current Ratio (CR) memiliki nilai 0.505842 , lain hal $\mathrm{t}_{\text {-tabel }}$ dengan sig $\alpha=5 \%$, df (36-7) $=29$ diperoleh nilai t. tabel sebesar 2.045. sehingga $t_{\text {-statistic }}$ Current Ratio (CR) $0.5058<\mathrm{t}_{\text {tabel }} 2.045$ dan nilai Prob. $0.6188>0,05$ sehingga 
dapat dikatakan bahwa $\mathrm{H}_{\mathrm{o}}$ diterima dan $\mathrm{H}_{6}$ ditolak, artinya variabel Current Ratio (CR) secara parsial tidak memiliki pengaruh terhadap Harga Saham.

Dalam hasil penelitian dikatakan bahwa Current Ratio (CR) tidak memilki pengaruh signifikan dan negatif terhadap Harga Saham. Hal tersebut mengartikan bahwa jika meningkatnya Current Ratio (CR) tidak selalu memiliki pengaruh baik kepada perusahaan, Current Ratio (CR) yang besar kemungkinan menggambarkan akan banyaknya dana piutang yang tidak tertagih secara maksimal dari perusahaan lain sehingga pada akhirnya dapat menghambat kemampuan perusahaan dalam memutar modalnya untuk meningkatkan labanya. melemahnya kemampuan perusahaan dalam menciptakan laba akan ditanggapi oleh para investor dengan diikuti oleh menurunnya harga saham perusahaan. Jika situasi ini seringkali terjadi diperusahaan maka dapat dikatakan bahwa hal-hal yang mempengaruhi Current Ratio (CR) terhadap harga saham tidak dapat diprediksi secara pasti, karena dipengaruhi oleh efektivitas perusahaan dalam menggunakan asset lancarnya. Dapat disimpulkan bahwa investor selalu mempertimbangkan rasio ini didalam menentukan harga saham perusahaan. sehingga dapat dikatakan bahwa Current Ratio (CR) memiliki pengaruh terhadap harga saham.

Hasil penelitian ini sejalan dengan hasil penelitian yang dilakukan oleh (Kundiman \& Hakim, 2014) dan (Novitasari \& EP, 2017) yang menyatakan bahwa Current Ratio (CR) tidak memiliki pengaruh terhadap harga saham.

- $\mathrm{t}_{\text {-statistic Return on Asset (ROA) }}$ memiliki nilai -2.756 , lain hal $\mathrm{t}_{\text {-tabel }}$ dengan sig $\alpha=5 \%$, df $(36-7)=29$ didapat nilai $\mathrm{t}_{\text {-tabel }}$ sebesar 2.045 . sehingga $\mathrm{t}_{\text {-statistic }}$ Return on Asset (ROA) $2.756>\mathrm{t}_{\text {-tabel }} 2.045$ dan nilai Prob. $0.0126<0,05$ sehingga dapat dikatakan bahwa $\mathrm{H}_{\mathrm{o}}$ ditolak dan $\mathrm{H}_{4}$ diterima, artinya variabel Return on Asset (ROA) secara parsial berpengaruh terhadap Harga Saham, dan $\mathrm{H}_{4}$ diterima menjelaskan bahwa adanya pengaruh yang signifikan antara Return on Asset (ROA) terhadap Harga Saham.

Dalam hasil penelitian dikatakan bahwa Return on Asset (ROA) memilki pengaruh signifikan dan negatif terhadap Harga Saham. Hal tersebut mengartikan bahwa menurunnya Return on Asset (ROA) akan menurunkan pula harga saham perusahaan. Hal ini menandakan sinyal bahwa menurunnya Return on Asset (ROA) tersebut bisa dikarenakan faktor kegagalan produk baru yang sedang dibuat oleh perusahaan, namun kenyataannya produk tersebut tidak mampu bersaing dengan produk sejenis di pasaran sehingga perusahaan mengalami kerugian. atau adanya faktor ketidakmampuan manajemen dalam mengelola aset di perusahaan tersebut sehingga menyebabkan biaya membesar dikarenakan biaya perawatan aset yang tidak diimbangi oleh laba yang dihasilkan. Sehingga laba yang diperoleh terkadang tidak menutupi biaya perawatan yang bersifat rutin,

Hasil penelitian ini sejalan dengan hasil penelitian yang dilakukan oleh (Rawung et al., 2017) \& (Prasetyaningrum, 2016) dan (Cahyaningrum \& Antikasari, 2017) yang menyatakan bahwa Return on Asset (ROA) memilki pengaruh terhadap Harga Saham. Namun, tidak sejalan dengan hasil penelitian yang dilakukan oleh (G.E.Y.Egam., V.Ilat., 2017) yang menyatakan bahwa Return on Asset (ROA) tidak memilki pengaruh terhadap Harga Saham.

- $\mathrm{t}_{\text {-statistic Return on Asset (ROA) }}$ memoderasi Arus Kas Operasi (CFO) sebesar -2.493, lain hal $\mathrm{t}_{\text {tabel }}$ dengan sig 
$\alpha=5 \%$, df (36-7) = 29 didapat nilai ttabel 2.045. sehingga $t_{\text {-statistic }}$ Ukuran Perusahaan 2.493> $\mathrm{t}_{\text {tabel }} 2.045$ dan nilai Prob. $0.0220<0,05$ sehingga dapat dikatakan bahwa $\mathrm{H}_{\mathrm{o}}$ ditolak dan $\mathrm{H}_{7}$ diterima, artinya variabel Return on Asset (ROA) mampu memoderasi Arus Kas Operasi (CFO) secara parsial terhadap harga Saham, dan $\mathrm{H}_{7}$ diterima bahwa terdapat pengaruh yang signifikan antara Return on Asset (ROA) dalam memoderasi Arus Kas Operasi (CFO) secara parsial terhadap harga Saham.

Dalam hasil penelitian dikatakan bahwa Return on Asset (ROA) memoderasi Arus Kas Operasi (CFO) memilki pengaruh signifikan dan negatif terhadap Harga Saham. Hal tersebut mengartikan bahwa jika Return on Asset (ROA) memiliki kemampuan dalam memoderasi Arus Kas Operasi (CFO) terhadap harga saham perusahaan. Dapat dikatakan bahwa Return on Asset (ROA) merupakan variabel moderasi dalam pengaruh Arus Kas Operasi (CFO) terhadap harga saham. Adanya kegagalan produk baru yang dikeluarkan oleh perusahaan tidak mampu bersaing dipasaran melalui informasi yang terkandung didalam Return on Asset (ROA) memberikan dampak yang negatif yang signifikan oleh investor dalam menilai prestasi kinerja perusahaan terhadap harga saham secara singkat waktu yakni tiga hari setelah diumumkan. Terdapatnya hasil negatif dalam penelitian ini juga menggambarkan tentang ketidakmampuan manajemen dalam mengelola aset di perusahaan tersebut sehingga menyebabkan biaya membesar dikarenakan biaya perawatan aset yang tidak diimbangi oleh pendapatan yang tergambar melalui informasi Arus Kas Operasi (CFO). Bahwasanya informasi yang digunakan oleh investor dalam menilai kinerja perusahaan perusahaan secara jangka panjang seperti dengan memakai data tahunan, yakni berdasarkan informasi yang terdapat dilaporan arus kas perusahaan. memiliki dampak signifikan pada harga saham perusahaan. Walau faktanya jika investor lebih menyukai menilai harga saham perusahaan melalui data laporan laba (rugi) tahunan. Dengan begitu, para investor akan berpikir ulang dalam menanamkan uangnya diperusahaan tersebut.

\section{Simpulan dan Saran}

\section{Simpulan}

Perkembagan Nilai Laba per Lembar Saham, Nilai Buku Ekuitas dan Komponen Arus Kas pada perusahaan manufaktur yang terdaftar di Bursa Efek Indonesia (BEI) 2015-2018. Berdasarkan hasil penelitian yang dilakukan dapat digambarkan bahwa variabel eksogen dalam penelitian ini mampu menjelaskan variasi naik/turunnya Harga Saham. Adapun besaran jumlah pengaruh semua variabel eksogen terhadap harga saham pada perusahaan manufaktur yang terdaftar di Bursa Efek Indonesia (BEI) 2015-2018 dalam penelitian ini memberikan kontribusi pengaruh sebesar $97.5 \%$, sedangkan kontribusi pengaruh dari faktor variabel lain yakni sebesar $2.9 \%$. adapun faktor variabel lain yang tidak termasuk kedalam model regresi dalam penelitian ini adalah Nilai Laba Per Lembar Saham, Nilai Buku Ekuitas Dan Return on Equity (ROE).

Berdasarkan hasil pengujian yang telah dilakukan dapat diketahui bahwa Laba per Lembar Saham dan Nilai Buku Ekuitas memiliki pengaruh positif terhadap Harga Saham pada perusahaan manufaktur yang terdaftar di Bursa Efek Indonesia (BEI) 2015-2018. lalu, Arus Kas Pendanaan, dan Return on Asset berpengaruh negatif pada perusahaan manufaktur yang terdaftar di Bursa Efek Indonesia (BEI) 2015-2018. Serta Return on Asset dapat memoderasi Arus Kas Operasi dengan meghasilkan 
pengaruh negatif terhadap harga Saham pada perusahaan manufaktur yang terdaftar di Bursa Efek Indonesia (BEI) 2015-2018. Sedangkan Arus Kas Operasi, Arus Kas Investasi, dan Current Ratio tidak berpengaruh terhadap harga Saham pada perusahaan manufaktur yang terdaftar di Bursa Efek Indonesia (BEI) 2015-2018.

\section{Saran}

Agar peneliti selanjutnya memasukkan beberapa kriteria tambahan terkait data yang akan digunakan, seperti perusahaan tidak mengalami kerugian selama tahun pengamatan, dan agar variabel moderating dalam penelitian ini dikembangkan dengan dijadikan sebagai variabel intervening. Namun tidak mengesampingkan tentang jumlah sampelnya, agar mendapatkan hasil yang lebih bervariasi. Dan jika pun menggunakan data terkait dengan tahun 2019 sebaiknya menggunakan Financial Distress sebagai variabel moderating, karena banyak perusahaan ditahun 2019 yang mengalami kegagalan keuangan dikarenakan pengaruh pandemic Covid 19.

\section{Daftar Pustaka}

Abimantrana, A. P. (2014). The Influence Of Financial Performance On Stock Price Around Publication Date Of Financial Statements (A Study In Food And Beverages Companies Listed On Bei). Jurnal Ilmiah Mahasiswa Feb Universitas Brawijaya, 2(2).

Asrianti, \& Rahim, S. (2015). Pengaruh Laba Dan Arus Kas Terhadap Harga Saham Perusahaan Lq 45 Di Bursa Efek Indonesia. Akuntansi Aktual, 3, Nomor 1, 17. Retrieved From Http://Journal2.Um.Ac.Id/Index.Php/J aa/Article/View/7181

Badri, D. M., \& Mayasari, M. (2016). Pengaruh Arus Kas Operasi Terhadap Harga (Studi Kasus Pada Perusahaan
Subsektor Pertambangan Batubara Yang Terdaftar Di Bei Saham Periode 2011-2013). Journal of Business Management Education (Jbme), 1(1), 196-204.

Https://Doi.Org/10.17509/Jbme.V1i1. 2288

Cahyaningrum, Y. W., \& Antikasari, T. W. (2017). Pengaruh Earning Per Share, Price To Book Value, Return On Asset, Dan Return On Equity Terhadap Harga Saham Sektor Keuangan. Jurnal Economia, 13(2), 191.

Https://Doi.Org/10.21831/Economia. V13i2.13961

Eksandy, A., \& Heriyanto, F. (2017). Metode Penelitian Akuntansi Dan Keuangan. Tangerang, Universitas Muhammadiyah Tangerang.

Feltham, G. A., \& Ohlson, J. A. (1995). Valuation And Clean Surplus Accounting For Operating And Financial Activities*. Contemporary Accounting Research, 11(2), 689731. Https://Doi.Org/10.1111/J.19113846.1995.Tb00462.X

G.E.Y.Egam., V.Ilat., S. P. (2017). Pengaruh Return On Asset (Roa), Return On Equity (Roe), Net Profit Margin (Npm), Dan Earning Per Share (Eps) Terhadap Harga Saham Perusahaan Yang Tergabung Dalam Indeks Lq45 Di Bursa Efek Indonesia Periode Tahun 2013-2015. Jurnal Emba, 5(1), 105-114.

Kundiman, A., \& Hakim, L. (2014). Pengaruh Current Ratio, Debt To Equity Ratio, Return On Asset, Return On Equity Terhadap Harga Saham Pada Indeks Lq. Among Makarti, 9(18), 80-98.

Lako, A. (2005). Relevansi Nilai Informasi Laporan Keuangan Untuk Investor Pasar Saham Indonesia: Suatu Bukti Empirirs Baru. Simponium Riset Ekonomi Ii.

Novitasari, R., \& Ep, A. (2017). Pengaruh Current Ratio (Cr), Debt To Equity 
Ratio (Der), Return On Assets (Roa), Dan Return On Equity (Roe) Terhadap Harga Saham (Studi Pada Perusahaan Sub Sektor Telekomunikasi Yang Terdaftar Di Bursa Efek Indonesia Periode 20132016). Jiab (Jurnal Ilmu Administrasi Dan Bisnis), 6(4), 5-24.

Prasetyaningrum, M. (2016). Profitabilitas Dan Return Saham: Peran Moderasi Arus Kas Operasi Dan Ukuran Perusahaan. Jurnal Ekonomi Dan Bisnis, $\quad 17(1), \quad 111$. Https://Doi.Org/10.24914/Jeb.V17i1. 242

Putra, A., Handayani, S., \& Pambudi, A. (2013). Perilaku Pengendalian Diri Pada Perilaku Manajemen Keuangan Personal Berdasarkan Pada Teori Planned Behavior Menggunakan Pendekatan Partial Least Square. $J p$ Feb Unsoed, 3(1), 309-314.

Rawung, F. E., Alexander, S. W., \& Kalalo, M. Y. B. (2017). Pengaruh Arus Kas Operasi Dan Return On Asset (Roa) Terhadap Harga Saham Studi Pada Perusahaan Perbankan Yang Terdaftar Di Bursa Efek Indonesia. Jurnal Riset Akuntansi Going Concern, 12(1), 29-41. Https://Doi.Org/10.1007/S11139-02000300-Y

Rizal, R. (2014). Pengaruh Arus Kas Dan Kebijakan Deviden Terhadap Harga Saham Di Bursa Efek Indonesia. Jurnal Manajemen Dan Akuntansi, 3(3).

Https://Doi.Org/10.4135/9781849209 403.N73

Sarifudin, A., \& Manaf, S. (2016). Pengaruh Arus Kas Operasi, Arus Kas Investasi, Arus Kas Pendanaan Dan Laba Bersih Terhadap Return Saham Pada Perusahaan Manufaktur Yang Terdaftar Di Bursa Efek Indonesia. Dharma Ekonomi, (43), 112.

Septya Nisa Sholekhah, A., Cholid Mawardi, Dan, Studi Akuntansi, P.,
\& Ekonomi Dan Bisnis, F. (2018). Pengaruh Arus Kas Dan Laba Terhadap Harga Saham ( Studi Empiris Pada Saham Perusahaan Jasa Transportasi Yang Go Public Di Bei Tahun 2014-2017 ). 07(07), 4759.

Sugiyono, P. D. (2017). Metode Penelitian Bisnis: Pendekatan Kuantitatif, Kualitatif, Kombinasi, Dan R\&D. Penerbit Cv. Alfabeta: Bandung.

Winarno, W. W. (2015). Analisis Ekonometrika Dan Statistika Dengan Eviews Edisi 4. Yogyakarta: Upp Stim Ykpn. 